JOURNAL OF

APPLIED

CRYSTALLOGRAPHY

ISSN 1600-5767

Keywords: book reviews.

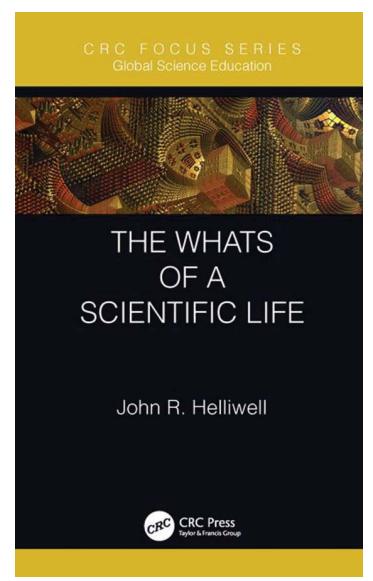

(C) 2020 International Union of Crystallography

\section{The Whats of a Scientific Life. By John R. Helliwell. CRC Press, 2019. Pp. 120. Price GBP 50.00 (hardback). ISBN 9780367233020.}

\author{
Claude Lecomte*
}

Cristallographie, Résonance Magnétique et Modélisations, CRM2, UMR 7036 CNRS - Université de Lorraine, F54506 Vandœuvre les Nancy, France. *Correspondence e-mail: claude.lecomte@univ-lorraine.fr

This small book (80 pages plus appendices) completes the trilogy of books by Professor J. R. Helliwell on his scientific life (hows, whys, whats). It is intended to interest a wide readership from scientific colleagues to school children. Its objective is to define science (Part I) and to describe career situations (Part II), what science has achieved (Part III), dependencies of science on mathematics (Part IV), processes for avoiding failures (Part V) and the International Council for Science (Part VI). These very short chapters are then followed by 35 pages of appendices copying reviews that the author wrote on books 'which impinge on the whats of a scientific life'.

Given the ambition of the book, one could expect more than 1000 pages, but in fact this six-part book is extremely short, subdivided into 21 nano chapters, some being just one page long.

Part I aspires to describe for a wide audience

\section{What is the Scientific Life?}

What is Physics?

What is Chemistry?

What is Biology?

Twelve pages are dedicated to these topics and they do not appear to answer any of these important questions satisfactorily, even at a pupil level.

For example, the chapter What is Physics? (2 pages) starts with the consideration that Newton was the father of physics (arguable, even if he was one of the greatest scientists of the world); then the second paragraph discusses the trajectory of the author - how he learned physics - including a discussion on Planck's constant and the uncertainty principle at a scientific level which seems too low for scientific colleagues and without interest for school children.

Part II (16 pages) would have been a very interesting topic, discussing how to make choices during a scientific career. It has been written as a car journey (excellent idea) with junctions, crossroads, roundabouts, traffic lights, obstacles, mountains. But it seems to come to a dead end. It mostly describes the ways the author took during his career; it may be interesting for a reader in the UK who has had the same trajectory, but probably not for an international audience. A long paragraph has been devoted to X-ray detectors to illustrate 'traffic lights', but the end reads a little like publicity for a detector company (two references out of six).

Part III is entitled Examples of What Science Delivers or Will Deliver in the Future. Two chapters describe X-ray and electron crystallography for biological applications; as the author is a recognized specialist it is a job well done, but scientific colleagues learn nothing. The other three chapters are too short to give sufficient information: chapters 14 and 15 on the 'Big Bang' (2 pages) and 'life elsewhere in the universe' (2 pages) only set out some basic questions associated with these topics. Predicting Climate Change on Earth (chapter 16) introduces the greenhouse effect and gives practical measures to reduce climate change, which have been written about and discussed already many times in popular newspapers.

Part IV is supposed to describe the role of mathematics across the disciplines: chosen examples are molecular dynamics (Newton and $F=m a$ ), crystal structures with the structure factor formula, and thermodynamics applied to the description of an interaction 
between a protein and its ligand. One might instead have expected a philosophical discussion on how the human brain has invented mathematics which - sometimes two centuries after its invention - explains nature, in particular fundamental physics: quantum mechanics, electromagnetism, optics, quasicrystallography. The title of this chapter seems too ambitious; Maths and X-ray Biocrystallography would have been more appropriate. Finally, data mining and engineering are (too) briefly discussed.

Part V is a short one-page chapter, which introduces successes, failures and checking.
Part VI concerns 'the coming together of the sciences and social sciences'; it is a one-page part to introduce the International Council for Science.

In addition, the book ends on My Reviews of Books Regarding the Whats of a Scientific Life.

In conclusion, I must write with a certain sadness that this too short book has very attractive title, parts and chapters but very little in the chapters. It is a great pity, knowing the very original, fruitful, interdisciplinary and international career of the author who always has been and still is a fervent supporter of science in general and crystallography in particular. 